\title{
Література
}

1. Жалдак М. І. Комп'ютерно-орієнтовані засоби навчання математики, фізики, інформатики / М. І. Жалдак, В. В. Лапінський, М. І. Шут // Інформатика. - 2006. - № 3-4. - С. 3-96. 2. Тарасова Н. В. Стратегия реализации компетентностного похода в образовании: историкопедагогический аспект / Н. В. Тарасова. - М.: ФИРО, 2007. - 52 с. - (Содержание, формы и методы обучения в высшей школе: Аналитические обзоры по основным направлениям развития высшего образования / ФИРО; Вып. 1). 3. Фролов Ю. В. Компетентностная модель как основа оценки качества подготовки специалистов / Ю. В. Фролов, Д. А. Махотин // Высшее образование сегодня. 2004. - №8. - С. 34-41. 4. Шишов С. Е. Понятие компетенции в контексте качества образования / С. Е. Шишов // Стандарты и мониторинг в образовании - 1999 - № 2. - С. 30-34. 5. Шкіль М. І. Реформування вищої педагогічної освіти / М. І. Шкіль // Освіта і управління. - 1997. - № 1. - С. 39-44.

\section{САМОСТІЙНА РОБОТА СТУДЕНТІВ МУЗИЧНО-ПЕДАГОГІЧНИХ ФАКУЛЬТЕТІВ НАД АНАЛІЗОМ ХОРОВИХ ТВОРІВ НА ЗАНЯТТЯХ ІЗ ХОРОВОГО ДИРИГУВАННЯ}

Кокарева Е. О. Самостійна робота студентів музично-педагогічних факультетів над аналізом хорових творів на заняттях із хорового диригування.

У статті розглянуто проблему самостійної роботи студентів музично-педагогічного факультету над аналізом хорових творів, здійснено пошук ефективних шляхів іiі розв'язання, розкрито специфіку роботи над нотним матеріалом на заняттях з хорового диригування.

Ключові слова: самостійна робота студентів, аналіз хорових творів, нотний матеріал, хорове диригування.

Кокарева Э. А. Самостоятельная работа студентов музыкально-педагогических факультетов над анализом хоровых произведений на занятиях по хоровому дирижированию.

В статье рассматривается проблема самостоятельной работы студентов музыкальнопедагогического факультета над анализом хоровых призведений, осуществлен поиск эффективных путей ее решения, раскрыта специфика работы над нотным материалом на занятиях по хоровому дирижированию.

Ключевые слова: самостоятельная работа студентов, анализ хоровых призведений, нотный материал, хоровое дирижирование.

Kokareva E. A. Individual work of students of music\&pedagogical departments at the analysis of choral works in the classroom for choral conducting.

The article deals with the problem of independent work of students of music and pedagogical department on the analysis of choral works; makes the search of effective ways of its decision; discloses specifics of the musical material in classes on choral conducting.

Key words: students' individual work, analysis of choral works, musical material, choral conducting.

У сучасній системі вищої освіти одним із найважливіших питань вдосконалення навчального процесу є пошук шляхів формування творчої самостійності студентів. Значну роль у розв'язанні поставленого питання відіграє самостійна робота студентів музично-педагогічних факультетів на заняттях із хорового диригування. Повноцінна професійна діяльність учителя музики неможлива без достатньої диригентсько-хорової підготовки, що передбачає як найважливіший аспект його постійну самостійну роботу та творче самовдосконалення.

Формування навичок самостійної діяльності студентів - одне з актуальних завдань сучасної освіти, а розвиток навичок самостійної роботи над нотним матеріалом, зокрема, хоровим твором, $\epsilon$ однією 3 обов'язкових умов успішного навчання студентів музично-педагогічних факультетів. У розв'язанні цієї проблеми значна роль відводиться формуванню в них умінь і навичок самостійного мислення i практичного застосування знань. Необхідно навчити студентів самостійно набувати знання з різних джерел інформації, оволодіти якомога більшою кількістю різноманітних видів і прийомів самостійної роботи.

Дисципліна «Хорове диригування» вважається однією із профілюючих на музичнопедагогічних факультетах (О. Апраксіна, Н. Гродзенська, Л. Хлєбнікова, В. Шацька та ін.) та 
відіграє важливу роль в індивідуальній підготовці студентів, оскільки пов'язана 3 практичною роботою над оволодінням знаннями, уміннями і навичками, дозволяє викладачеві глибше вивчити психологічні особливості студента, визначити рівень його музично-естетичних здібностей, знайти шляхи їх ефективного розвитку. Саме тому хорове диригування створює сприятливі умови для організації й керівництва формуванням у студентів умінь самостійно аналізувати музичні твори.

Дослідженню стану проблеми самостійної роботи студента музично-педагогічного факультету над аналізом хорових творів і диригентської підготовки загалом присвятили свої роботи Л. Андреєва, Л. Безбородова, В. Живов, Н. Колесса, О. Коломоєць, Г. Март’янова, I. Мусін, Г. Стулова та ін.

Незважаючи на достатнє висвітлення окресленої проблеми у музично-педагогічній літературі, на практиці вона не є розв'язаною повною мірою. У зв'язку зі зміною навчальних програм дисципліна, засвоєння якої готує студента до аналізу хорових творів, - «Хороведення» вивчається на 1 курсі, коли значна кількість студентів ще не має належної музичної підготовки. Тому свідоме сприйняття студентами у 1 семестрі названої дисципліни є для них не завжди можливим і перед викладачами дисциплін «Хороведення» та «Хорове диригування» постає спільне завдання знаходження шляхів розв'язання зазначеної проблеми.

Розв'язання окресленої проблеми можливе завдяки уточненню теоретичної бази, систематичної роботи викладачів зі студентами на заняттях із хорового диригування, створенню умов для їхньої самостійної роботи й постійного контролю над нею.

Meта статmi - висвітлити проблему самостійної роботи студента музично-педагогічного факультету над аналізом хорових творів та здійснити пошук ефективних шляхів її розв'язання.

Більшість науковців (А. Буров, В. Ванслов, Н. Ветлугина, Л. Виготський, В. Сухомлинський, Б. Теплов та ін.) найважливішими процесами здійснення самостійної роботи вважають формування вмінь виокремлювати, порівнювати, зіставляти, аналізувати. Сучасні дослідження в галузі сприйняття музики (А. Костюк, В. Медушевський, Є. Назайкинський) переконують у тому, що для повноцінного сприйняття музики необхідно розвивати здатність розуміти ії естетичну сутність, а це неможливо без засвоєння умінь самостійно аналізувати музичні твори. Самостійність - одна 3 провідних якостей особистості, що виражається в умінні ставити перед собою певні цілі та досягати їх власними зусиллями. Розвиток самостійності допомагає майбутньому вчителеві оволодіти навичками самостійної роботи, які дозволять йому впродовж всіх років навчання i, що важливо - після завершення навчання отримувати знання самостійно.

Самостійна робота студентів - це форма організації їхньої навчальної діяльності, що здійснюється під прямим або непрямим керівництвом викладача, під час якої вони частково або повністю самостійно виконують завдання різного виду задля розвитку знань, умінь, навичок і особистісних якостей [1, с. 265]. Саме самостійна робота сприяє високій культурі розумової праці, яка передбачає не лише техніку читання, вивчення книги, музичних творів, ведення записів, а передовсім потребу в самостійній діяльності, прагнення вникнути в сутність питання, ставити та розв'язувати нові проблеми. У процесі такої праці найповніше виявляються індивідуальні здібності студентів, їхні схильності й інтереси, які сприяють розвитку уміння аналізувати факти і явища, вчать самостійному мисленню, яке сприяє творчому розвитку і створенню власних думок, поглядів, уявлень, переконань.

Наявні різні позиції щодо формування самостійності студентів, яка тісно пов'язана із розвитком їхніх пізнавальних інтересів. Інтерес будить самостійність, а остання характеризує розвиток інтересу. Справжній інтерес виявляється у стійкому, терплячому і творчому виконанні тривалих самостійних робіт.

Самостійність студентів на заняттях із хорового диригування виявляєтьсяя насамперед у потребі й умінні самостійно мислити, здатності орієнтуватися в новій ситуації, самому бачити проблеми і шляхи їх розв'язання. Необхідно зазначити, що поступове зростання складності самостійної роботи повинно здійснюватися за основними трьома напрямками:

- шляхом збільшення обсягу завдань та тривалості самостійної роботи;

- шляхом ускладнення змісту завдань;

- шляхом зміни способів інструктажу й поступового зменшення обсягу допомоги з боку викладача. 
Аналіз музичних творів - важливий аспект у професійній підготовці майбутнього вчителя музики, оскільки він мобілізує знання, волю, здібності і закладає фундамент ефективної самостійної практичної діяльності вчителя в школі. Потреба в розробленні системи виконавського аналізу з самого початку навчання в класі диригування пов'язана 3 тим, що студенти 1 курсу музично-педагогічного факультету в переважній більшості не мають навичок цілісного аналізу, оскільки більшість з них не мають хорової підготовки. Отже, викладач з хорового диригування, плануючи індивідуальні заняття зі студентами, повинен це враховувати. Незважаючи на вищесказане, не можна зводити заняття 3 диригування до оволодіння системою диригентських жестів. Головним завданням цієї дисципліни, що готує вчителя музики, повинно бути виховання музиканта, який розуміє музичне мистецтво, його ідейно-емоційний зміст, уміє вдумливо ставитися до музичного тексту, використаних у творі засобів художнього втілення музичного задуму. Тільки на такій основі можна розв’язувати питання диригентського навчання у ВНЗ.

Досить часто виконавці висловлюють думки, ніби аналітичне ознайомлення з музикою заважає безпосередньому ії сприйняттю. Ми погоджуємося з В. Живовим [3], який не поділяє такого бачення, адже багато відомих музикантів-виконавців, ретельно аналізуючи музичні твори, визнають, що твір, пізнаний у найдрібніших його деталях, стає їм ще ближчим. Розглядаючи історичний аспект цього питання, можна прослідкувати, що кращі музиканти $\epsilon$ авторами грунтовних аналітичних розборів (Г. Бюлов, Ф. Бузоні, Б. Вальтер, А. Корто, К. Пігров, В. Соколов П. Чесноков).

Звичайно, виконавцеві багато «відкривається» і за безпосереднього сприйняття музики. Але аналітичне вивчення твору, не претендуючи на визначальну роль у роботі музиканта, розвиває і поглиблює його уявлення про художній зміст тексту і музики, робить твір ближче i, головне, сприяє виникненню об'єктивного і водночас індивідуального виконавського трактування. У контексті нашого дослідження слушною вважаємо думку В. Живової: «Ясне уявлення про взаємодію художніх засобів, розуміння виразних можливостей елементів музичної мови, збагнення законів формоутворення, здатність схоплювати характерні для цього автора вияви його стилю - всі ці якості, виховані в результаті аналітичної діяльності, уточнюють i загострюють сприйняття музики, розширюють інтелектуальний горизонт, допомагають самостійно орієнтуватися у формі і музичній мові твору, розвивають спостережливість, сприяють кращому запам'ятовуванню музичного матеріалу» $[3$, с. 5].

Особливо велике значення має аналітична інтеграція твору для вчителя музики, що виконує функції хорового диригента, який повинен неодмінно усвідомити своє ставлення до того або того музичного явища, обгрунтувати його і мотивувати учнів до його вивчення, коли студент вийде за стіни ВНЗ і працюватиме в системі освіти. Отже, формування у студентів умінь аналізувати хорові твори створює сприятливе підгрунтя для перенесення сформованих умінь на шкільний репертуар, а використовувані методичні прийоми і засоби необхідні для роботи з учнями. Значимість аналізу твору для майбутнього вчителя музики зумовлена також іншими особливостями шкільної роботи, яка, окрім розучування і виконання пісень, передбачає слухання музики, позашкільну роботу тощо. Усе це вимагає від педагога чіткого уявлення про особливості змісту і форми творів, роль різних композиційних прийомів і музично-виразних засобів.

Аналіз хорового твору, метою якого є створення продуманої його інтерпретації, сприяє активізації інтересу студентів до твору, формуванню власного творчого ставлення до музики. Оволодіння методом аналізу хорового твору слід розглядати як процес поетапного формування складної за структурою пізнавальної дії. Наприклад, Л. Безбородова [2] вважає, що самостійну роботу над хоровою партитурою можна умовно розбити на чотири основні етапи: вокальний, інструментальний, аналітичний і диригентський, які органічно пов'язані між собою. Перший етап присвячений створенню музично-слухового уявлення про хорову партитуру. Другий стосується поступового заглиблення в сутність твору, що вивчається. Третій необхідний для створення загального уявлення щодо основного художнього образу. I, нарешті, на четвертому етапі відбувається відбір диригентських жестів й оволодіння пластичними засобами вираження, необхідними для реалізації художнього змісту партитури.

В. Живов [3] виокремлює план аналізу вокально-хорового твору, який повинен надати змогу відповісти на чотири головні питання.

1. Яку думку, зміст передають автори (аналіз поетичного тексту і музичних засобів, за допомогою яких композитор передає той або інший зміст)? 
2. Якими загальновиконавськими і спеціальними вокально-хоровими засобами музикант може найбільш переконливо втілити художньо-образний зміст твору (аналіз темпу, динаміки, агогіки, тембру, фразування, характеру звуковедення й інших засобів, що створюють у сукупності виконавський художній образ)?

3. Якими диригентськими засобами та прийомами можна 3 найбільшою адекватністю реалізувати виконавський художній образ (аналіз диригентських засобів виразності)?

4. Які вокальні, ритмічні, інтонаційні, ансамблеві, диригентські й інші труднощі можуть виникнути перед диригентом в процесі реалізації «ідеального» виконавського задуму (аналіз вокально-хорових та інших технічних труднощів)?

О. Коломоєць [4], у свою чергу, виокремлює такий план аналізу хорової партитури:

- загальний аналіз (відомості про авторів, жанрова належність, зміст твору, загальний характер твору);

- музично-теоретичний аналіз (структура музичної форми, ладотональність, гармонія, метроритм, темп, особливості фактури викладу, характеристика основної мелодії як музичної виразності, значення ролі акомпанементу);

- вокально-хоровий аналіз (тип і вид хору, наявність дивізі та унісонів, загальний діапазон хору і загальна теситура, прийом звуковедення, дихання, аналіз і характеристика кожної хорової партії - ансамбль і стрій);

- виконавський аналіз (аналіз динаміки і кульмінацій, аналіз фразування, змістові цезури, відповідність або розбіжність логічних наголосів і музичних кульмінацій, диригентські труднощі).

Підсумовуючи вищесказане, необхідно зазначити, що під час аналізу хорових творів студентами ВНЗ слід робити акцент на їхньому творчому аналізі, що носить дослідницький характер. У процесі аналітичного вивчення твору студент повинен самостійно зробити власні висновки про зміст, форму твору; правомірність вибору композитором тих або тих засобів для втілення цього образу; відповідність художніх образів поетичного тексту й музики; секрет виразної дії музики. Завдання педагога - створити під час роботи над аналізом хорового твору атмосферу творчого пошуку, збудити у студента відчуття першовідкривача [3]. Здійснивши певну дослідницьку роботу, студент цілком здатний висловити оригінальні думки про вже достатньо відомий твір. Із першого курсу студент може й повинен проводити самостійне дослідження, зіставляти факти, робити самостійні узагальнення, висновки, у такий спосіб він оволодіє навичками самостійної роботи над хоровими творами, виявлятиме потребу в самоосвіті й постійному самовдосконаленні.

Наше дослідження не вичерпує всіх аспектів самостійної роботи студентів музичнопедагогічних факультетів над аналізом хорових творів на заняттях із хорового диригування. Подальшого вивчення потребують особливості аналізу інструментальних і вокальних творів та можливості використання евристичних методів задля підвищення ефективності аналізу музичних творів.

\section{Література}

1. Андреев В. И. Педагогика: учебный курс для творческого саморазвития / В. И. Андреев. Казань : Центр инновационных технологий, 2000. - 608 с. 2. Безбородова Л. А. Дирижирование: [учеб. пособ. для студ. пед. ин-тов по спец. «Музыка» и уч-ся пед. уч-щ по спец. «Муз. воспитание»] / Л. А. Безбородова. - М. : Просвещение, 1990. - 159 с. 3. Живов В. Л. Исполнительский анализ хорового произведения / В. Л. Живов. - М. : Музыка, 1987. - 95 с. 4. Коломоєць О. М. Хорознавство: [навч. посіб.] / О. М. Коломоєць. - К. : Либідь, 2001. - 168 с. 5. Мусин И. А. О воспитании дирижера: очерки / И. А. Мусин. - Л. : Музыка, 1987. - 247 с.

УДК: 001.89

Наталя Кулєиова

\section{КОНЦЕПТУАЛЬНА МОДЕЛЬ ЗДІЙСНЕННЯ НАУКОВОГО ДОСЛІДЖЕННЯ СТУДЕНТАМИ ВИЩОГО НАВЧАЛЬНОГО ЗАКЛАДУ}

Кулєшова Н. В. Концептуальна модель здійснення наукового дослідження студентами вищого навчального закладу.

У статті розроблено концептуальну модель, що дозволяє системно підходити до проведення наукових досліджень студентами вищого навчального закладу. На базі моделі 